\title{
Difficulties in Value Creation: Telecom New Zealand's Acquisition of AAPT Ltd.
}

Dissertation submitted to Auckland University of Technology in partial fulfilment of the degree of Master of Business

by Zoltan Toth 


\section{TABLE OF CONTENTS}

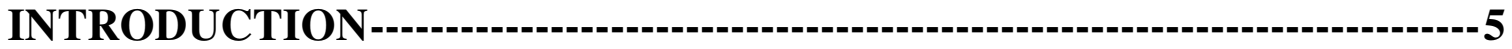

PRIVATISATION AND LIBERALISATION OF THE

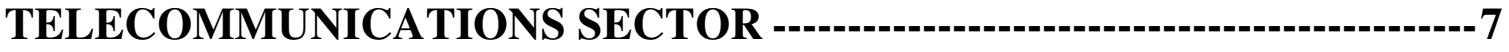

OVERVIEW OF THE NEW ZEALAND TELECOMMUNICATIONS

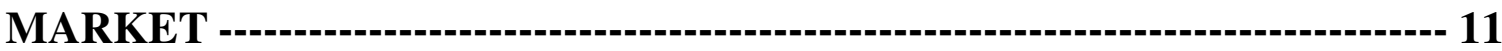

OVERVIEW OF THE AUSTRALIAN TELECOMMUNICATIONS

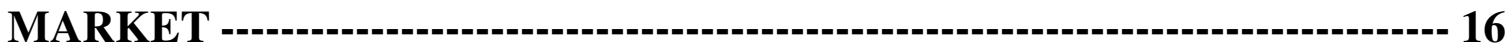

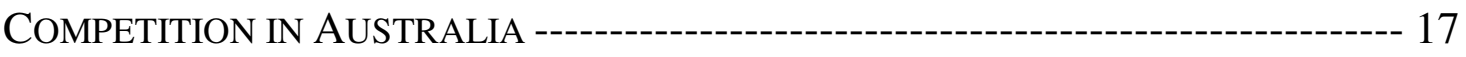

ACQUISITION OF AAPT --.-- 20

TELECOM NZ'S MOTIVATIONS---------------------------------------- 20

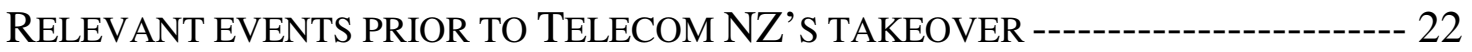

CHRONOLOGY OF THE TAKEOVER----------------------------------------- 24

EMPIRICAL STUDY ON ANNOUNCEMENT EFFECTS----------------------------------- 27

VALUATION OF AAPT ---:- 34

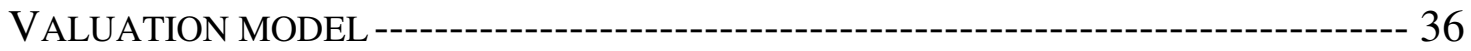

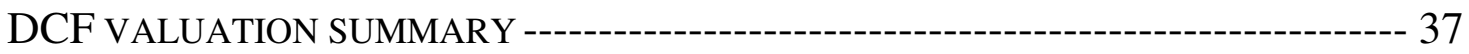

REVENUE ------------------------------------------------------ 39

OPERATING COSTS AND CAPITAL EXPENDITURE------------------------------- 41

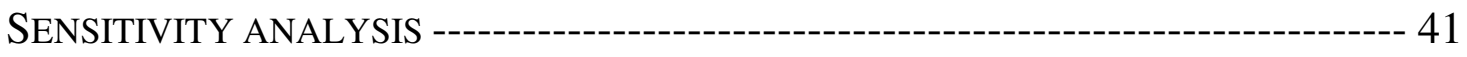

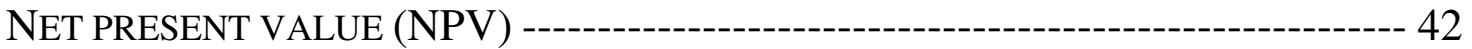

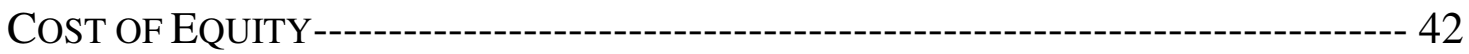

COST OF DEBT --------------------------- ERROR! BOOKMARK NOT DEFINED.

WEIGHTED AVERAGE COST OF CAPITAL---------------------------------- 45

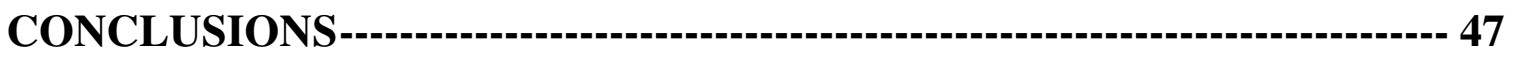

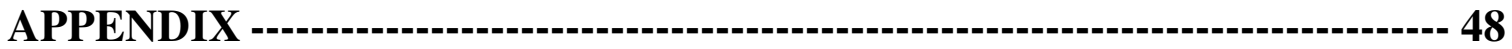

REFERENCES --- 
I hereby declare that this submission is my own work and that, to the best of my knowledge and belief, it contains no material previously published or written by another person (except where explicitly defined in the acknowledgments), nor material which to a substantial extent has been submitted for the award of any other degree or diploma of a university or other institution of higher learning.

Zoltan Toth, 2006 


\begin{abstract}
I provide an overview of the Australian and New Zealand telecommunications markets through Telecom New Zealand's (TCNZ) acquisition of AAPT Ltd in 2000 which amounted to more than NZ\$2 billion. Few years later and after writing off approximately NZ $\$ 1$ billion, TCNZ is considering a sell-off at a considerable loss. I discuss the strategic reasons behind the acquisition and explain how smaller telcos are struggling to compete with the incumbent telecom in Australia. I further conduct an event study to assess the impact of the acquisition on both TCNZ's and AAPT's share prices and look at some of the post-acquisition issues. I finally provide a valuation analysis on the AAPT business.
\end{abstract}

I would like to thank Alireza Tourani-Rad for his contribution and support in the preparation of this paper 


\section{INTRODUCTION}

In 2000 Telecom New Zealand, the largest listed company in New Zealand, acquired AAPT Ltd. AAPT was Australia's third largest telecommunication firm offering voice (local, national and international), data, mobile, internet (broadband and dial up) and pay TV services nationwide to residential, and corporate customers. At the time, Telecom New Zealand Chief Executive Roderick Deane said "Telecom's international strategies include growing our trans-Tasman business. AAPT provides Telecom with facilities-based participation in the fastgrowing Australian market. Increasing our shareholding should enable both Telecom and AAPT to achieve key strategic goals sooner than if they were to proceed independently"1. By mid 2001, Telecom had to reduce the value of AAPT in its books by approximately NZ $\$ 1$ billion. At the time of writing this paper, late2005, Telecom was considering a potential sale of AAPT at a considerable loss.

A number studies have examined the wealth impact of shareholders involved in cross-border mergers and acquisitions. For example, Doukas and Travlos (1988), Fatemi and Furtado (1988) and Markides and Ittner (1994) investigated international takeovers by the US companies where on average they found positive but rather negligible abnormal returns. Kang (1993) studied Japanese acquisitions

\footnotetext{
${ }^{1}$ AAPT Ltd's Australia Stock Exchange announcement: “Telecom New Zealand announces Takeover Offer for AAPT", Document date: 15 Sep 1999 (http://www.asx.com.au/asx/statistics/showSignalgDetail.do?issuerId=3829\&announcementId=576106)
} 
of US firms. He found that these transactions created significant wealth gains for shareholders of bidding firms. Corhay and Tourani-Rad (2000) found weak evidence that cross-border acquisitions by Dutch firms are wealth-creating activities. The available empirical research on cross-border, as a whole, indicate little or no significant gains for the bidding firms shareholders and as Markides and Ittner comments "The stock market, therefore, is not very enthusiastic about international acquisitions. It does not view them, however, as good news".

Whether international take-over creates value is far from settled and our aim in this paper is to add to this by examining in details the case of a single and major international take-over. In the rest of the paper, I provide an overview of the telecommunication markets and the prevalent regulatory issues in Australia and New Zealand. I present the strategic reasons behind the acquisition and explains how smaller telcos are struggling to compete with the incumbent telecom in Australia. I further conduct an event study to assess the impact of the acquisition on share prices of Telecom and AAPT and look at some of the financial issues involved and report on the post-acquisition situation that summarizes some of the difficulties faced by TCNZ in creating value in this transaction. I finally provide a valuation analysis on the AAPT business. 


\section{PRIVATISATION AND LIBERALISATION OF THE TELECOMMUNICATIONS SECTOR}

The worldwide telecommunications sector went through a major privatisation and liberalisation period in the 1980's and 1990's (Boylaud, 2000). Until the 80's, telecommunication services in most countries had been monopolistic public enterprises.

International studies show that telecommunications infrastructure serves as a major source of economic growth. Greenstein and Spiller (1995) find a positive and significant impact of telecommunication infrastructure (as measured by the amount of fiber-optic cable employed) on economic growth in the United States. Datta and Agarwal (2004) indicate that telecommunications infrastructure plays a positive and significant role in economic growth in 22 OECD countries from 1980-1992.

Governments worldwide have recognised the increasing need for an efficiently operating telecommunication environment. The conventional state owned monopolistic telecommunication enterprises could no longer meet these requirements and could not keep up with the development of new technologies. The traditional tendency in the telecommunications sector was to build the largest possible network at the lowest possible cost, without taking updating and upgrading requirements into account (Giray, 2006). A country with a state owned, inefficient telco with obsolete network is not likely to be able to successfully participate in the global economy and eventually will lag behind the more advanced economies.

As a result, many governments had come to the conclusion that allowing the private sector to enter the telecommunications market will boost the economy and 
allow a cutting edge telecom market to develop. They have initiated privatisation programs to sell their stake to private companies and establish the basis for a growing telco industry.

Privatisation is just the first step and often followed by the liberalisation of the market. These two terms are related and often used together but there is a clear distinction between them. Privatisation is the conversion of a state enterprise to private-sector ownership where the state enterprise may be privatised as either a monopolistic or competitive entity. Liberalization, in contrast, is the opening of a monopolistic market to competitive provision of facilities and services. Whether the former monopoly operator is a state enterprise or a private enterprise is not the primary consideration.

The most important factor to privatisation and liberalisation is clear government goals for the telecom sector and adoption of policies to achieve these goals. The pricing rules must be well defined and the government must clarify the role of the regulatory authority and its decision making process. The change process must be transparent and predictable.

From the investors' point of view, the key factor is the regulatory risks and its potential effects on future cash flows. Investors must be aware that in the telecom market regulatory changes can have major impacts on the market participants and eventually can rearrange the whole telecom market by legislative changes.

Often governments are tempted to view privatisation as a quick cash injection to the general treasury and fail to accompany a telecom privatisation with policies necessary to create competition and a vibrating telecommunications market. 
Giray (2006) finds that progress of reforms in the telecommunications sector has been very successful, but results vary according to conditions. In many European countries for example, privatisation and liberalisation opened up opportunities for many telcos creating a thriving competitive environment. In contrast, some other countries such as Argentina and Mexico successfully privatised public telecommunication monopolies, but postponed opening up the sector fully to competition. As a result they faced slower growth in the sector and higher prices than other countries.

Even though one can observe many examples of successful privatisation and liberalisation process in a number of countries, the incumbent telcos have typically maintained their dominant position and control the majority of the telecommunications market. Furthermore, if the legislation is not protective enough, incumbents often tend to eliminate competition by exploiting the loopholes within the legislation.

In recent years, governments trying to enhance competition have introduced changes in the regulatory regimes. One of the major initiatives was the local loop unbundling (LLU). "LLU is the process where telecommunications providers can gain direct use of the local loop to deliver their services. This will entail them installing their own telecommunications equipment at the incumbent's pre-existing sites". ${ }^{2}$ This system allows smaller telcos without local network to gain access and utilise the local loop without having to invest into building up their own local network. It is imperative that the pricing of the access fee is correctly set in order to ensure the successful utilisation of this policy.

Another remarkable initiative that some governments have introduced is operational and structural separation. Both measures are applied to create a clear

\footnotetext{
${ }^{2}$ Telecom NZ's website (http://www.telecom.co.nz/content/0,8748,205349-204244,00.html)
} 
picture for incumbents' wholesale pricing. Operational separation is "a legal framework designed to address concerns that arise from the incumbent's ownership of the infrastructure which other telecommunications companies need to access and interconnect with in order to provide services to consumers. Under operational separation, the incumbent must maintain separate retail, wholesale and key network services business units. Wholesale business units must be located in premises that are secure and separate from retail business units and staff members may not be employed by more than one business unit."3 Operational separation involves the accounting separation of the retail and wholesale side of the incumbent telco thereby creating a transparent wholesale pricing structure.

Another step further in the process is structural separation. It requires the retail and wholesale part of the company to form two separate legal entities. The wholesale company would sell the network services to the telco market participants including the newly formed retail side of the former incumbent.

There has been some academic debate as to the full effectiveness of LLU and structural/operational separation in recent years, but one thing appears to be certain: it has significantly enhanced competition in those countries wherever they have been introduced.

\footnotetext{
${ }^{3}$ Website of Australia's Department of Communications, Information Technology and the Arts (http://www.dcita.gov.au/tel/connect_australia/operational_separation)
} 


\section{OVERVIEW OF THE NEW ZEALAND TELECOMMUNICATIONS MARKET}

Telecom Corporation New Zealand (TCNZ) is New Zealand's largest telecommunications company. It provides a full range of fixed line voice and data, mobile, and Internet services.

TCNZ was separated from New Zealand Post Office in 1987 as a first step of sweeping market deregulation policies implemented in New Zealand in late 1980s' by the labour government. The company was subsequently sold to two US based telecommunication companies: Bell Atlantic and Ameritech for \$NZ 4,250 million. At the same time it got listed on New York, Australian and New Zealand stock exchanges. A few years later they both sold their shares on the stock exchange and the shares have ultimately been acquired by a variety of institutional investors. ${ }^{4}$

The second largest company in the fixed line market in New Zealand is TelstraClear, the Australian incumbent telco's NZ subsidiary. Telstra entered the New Zealand market 1996 and created its present form by acquiring Saturn Communications and later Clear Communications Ltd. The company offers voice,

\footnotetext{
${ }^{4}$ TCNZ's website (http://www.telecom.co.nz/content/0,2502,200633-1548,00.html)
} 
broadband internet, and wireless services in New Zealand. By 2005 TelstraClear reached $35 \%-40 \%$ of corporate voice calling market. ${ }^{5}$

TelstraClear has a $6000 \mathrm{~km}$ long fibre optic network connecting major cities and regional centres. The network is linked to Telstra's Australian network providing an international extension to the NZ core network and allowing the company to handle increasing network traffic and in the future VoiP (Voice Over Internet Protocol) and a range of multimedia services. The company also has a wireless network which is utilized to provide broadband access to remote areas when DSL (Digital Subscribers Line) services are unavailable.

Regulations in NZ required Telecom to open up its services to other players in the market. Telecom provides the vast majority of its fixed line services for wholesale customers at a price determined by the regulator.

Telecom operates NZ's major national telephone network. More than $99 \%$ of the public switching network lines are connected to digital exchanges. In voice services Telecom maintains its 95\% share of the local access market and around $80 \%$ of the overall voice market. ${ }^{6}$ The remainder of the market lies mainly with TelstraClear. Although there are now a number of other companies providing

\footnotetext{
${ }^{5}$ Phil Harpur (2006), Telecoms Overview, Statistics and Analyses in new Zealand 2006, Paul Budde Communications Pty Ltd

${ }^{6}$ Hot Telecoms (www.hottelecoms.com) - Country Profile New Zealand, November 2005
} 
fixed line service (local and international); their market share remains relatively small. Interconnection agreements have been signed between Telecom and the other players and in some instances the companies have agreements with each other.

Though there has been some development in competition for the smaller companies and margins improved through regulated deals regarding wholesale activity and interconnection, local loop unbundling still has not been permitted. ${ }^{7}$ In 2005 TelstraClear gave up its plans to build up an alternative local and nationwide network to compete with Telecom in the fixed line business. Instead TelstraClear would remain a niche player concentrating on its residential markets in NZ's second and third largest cities (Wellington and Christchurch) and its government and business customers looking after their trans-Tasman relations. This strategic decision strengthened further the Telecom's dominant position in the shrinking voice market.

Telecom also owns a data services network (called Digital Services Transmission Network - DSTN) which enables to offer data transmission services like private office network, datalink and ATM services.

\footnotetext{
${ }^{7}$ In May 2006 the New Zealand government announced a decision to go ahead with unbundling from 2007. However, the legal framework and the exact details of this matter are yet to be determined.
} 
In 2004, Telecom announced its plans to implement a new Next Generation Network (NGN). The total cost of this investment is NZ\$1.4 billion and is expected to be completed by 2012 . The project aims to multiply the capacity of the core network by implementing an IP (Internet Protocol) based data and voice transmission infrastructure. ${ }^{8}$

In the wireless market Telecom NZ and Vodafone are the key players. Vodafone's predecessor Bell South established NZ's first mobile service to compete with Telecom. Vodafone acquired the company in 1998 and made large investments in its network and distribution system. As a result, the company managed to catch up with and then exceed Telecom's market share and established its position as market leader. Through its wireless network, the company offers voice, data and value added mobile services. More recently Vodafone has lost a significant portion of its market share due to Telecom's successful 3G campaign and an attractive offer of low texting. ${ }^{9}$

Vodafone is operating its own $2 \mathrm{G}\left(2^{\text {nd }}\right.$ Generation) fully digital GSM network on 900 and $1800 \mathrm{Mhz}$ which covers $97 \%$ of the population. In 2005 they officially launched a W-CDMA (Wideband Code Division Multiple Access) based 3G ( $3^{\text {rd }}$

\footnotetext{
${ }^{8}$ Alcatel company announcement (http://www.home.alcatel.com/vpr/vpr.nsf/DateKey/30082005uk)

${ }^{9}$ Phil Harpur (2006), Telecoms Overview, Statistics and Analyses in new Zealand 2006, Paul Budde Communications Pty Ltd
} 
Generation) network. The system enables them to offer video calling and it initially covers major cities reaching around one third of the population.

In the internet dial up and broadband market Telecom's dominance is most important. Other Internet Services Providers (such as Ihug, Orcon, Maxnet and CallPus) are resellers of Telecom's services. New Zealand has been behind in the broadband uptake in an international comparison and the New Zealand government has developed plans to remedy this situation. 


\section{OVERVIEW OF THE AUSTRALIAN TELECOMMUNICATIONS MARKET}

The Australian telecommunications market has been dominated by the two large companies, Telstra and Optus, sharing a 75\% of the market revenue and a number of second tier companies operating in a highly regulated and competitive environment. There is over 700 companies in the $2^{\text {nd }}$ tier market, however the distribution is uneven; the top ten players share over $90 \%$ of all revenues. ${ }^{10}$

The market leader is Telstra Corporation owned by the Australian Government (51\%). The company has a dominant position in the fixed line telephone services, market leader in mobile as well as in data (dial-up and broadband) services.

Optus is a wholly-owned subsidiary of SingTel and is the second largest telco in the Australian market. Optus was established in 1991 and started to offer fixed line services mainly by reselling Telstra's national long distance and international telephone services. In 1992 the company won the second carrier license enabling it to offer unrestricted local, national long distance, international and mobile telephone services.

\footnotetext{
${ }^{10}$ Australia Telecoms Industry - Overview and Statistics 2005/2006, Paul Budde Communications Pty Ltd
} 
AAPT was established in 1991 when the financial and data services division was separated from the Australian Associated Press, Australia's leading national news, information and communications group. The company started operating as the first competitor to Telstra in long distance voice and data services. Throughout the years, AAPT has always been a significant player in the market, challenging the big telcos, leading the innovation and generating growth by natural market share increase and active acquisition policy which has made it attractive for potential buyers (for an overview of milestones in AAPT history please refer to the Appendix).

\section{Competition in Australia}

The regulatory environment in Australia has not been favourable to smaller telecommunication companies. Although the Australian government's aim to encourage competition that drives new services and lower prices has shown some improvements over the years, in reality this is still not a classic free market where competitors have equal opportunities.

In addition to the regulatory environment, the other restricting element is the lack of infrastructure small companies have to face and the high level of risk to invest into building up their own network. Consequently they do not have many viable options but to resell Telstra's various products. 
Competition in the telecommunications sector began in the early 90's when the government decided to open up the market to other carriers and give permission for them to resell Telstra's services, mainly long distance and international calling services.

In 1992 Optus obtained the second carrier license and started to offer fixed line and mobile services. The next major player in the mobile scene was Vodafone who entered the market in 1993 offering services over its own mobile network.

In 1997, the Australian Government introduced a new regulatory regime which allowed telecommunication companies to openly compete within all segments of the telecommunication industry. As a result, over 700 communication service providers have been established since then. Most of these companies are using Telstra's wholesale services and competing in the retail market. Though this number is quite impressive in size, Telstra has managed to retain its dominant position across all market of the telecom sector.

By June 2005, Telstra's estimated retail market share was $73 \%$ in local calls, $62 \%$ in domestic long distance minutes, $51 \%$ in international long distance minutes, 
$45 \%$ in mobile services, $28 \%$ in dial up internet services, $41 \%$ in broadband services and $60 \%$ in subscription television services. ${ }^{11}$

\footnotetext{
${ }^{11}$ Telstra Australia Ltd Annual Report 2005
} 


\section{ACQUISITION OF AAPT}

\section{Telecom NZ's motivations}

From the early years on Telecom has been planning a strategic Australian presence. Trans-Tasman telecommunication businesses have more than 100 years of history. Since international telecommunication lines have been set up, both major companies (and their predecessors) operated in both countries.

It has become even more important since the two countries have developed into highly integrated economies and an increasing number of companies are operating on both sides of the Tasman.

Driven by the liberalisation process during the late 80 's and early 90 's, both companies felt that it would be a perfect opportunity to increase their presence on the other side and attempt to take a chunk of the market which was still dominated by the domestic incumbent company.

Telecom NZ's decision to purchase AAPT had several reasons. One of the most important aspects is the strategic considerations. Telecom's presence in the Australian market was very limited. In order to service the increasing demand for Trans-Tasman connections from both sides, Telecom needed a strong and sizeable company to establish its presence.

It is also very important to note that Telecom had some infrastructure capacity that had not been entirely utilized. A new investment with reasonable incremental volumes could ensure a better utilisation of the infrastructure. 
Another aspect of this issue is that prior to the acquisition in the mid 90's Telstra had shown an increasing interest in the New Zealand market. The company had various plans to invest into and build up an alternative network which could have been developed into a wide range of competing services. This has been considered as a major risk by Telecom's management and they felt that through the purchase of AAPT, this risk could be diversified. They also believed that the Australian market would provide a steady revenue growth that may offset the eventual reduction in domestic revenues. Some market analysts suggested that Telecom NZ's management had plans to move the company's head office across the Tasman and create an Australian based fully integrated telecommunication company operating in both countries. This plan however has never been officially confirmed.

Market analysts also speculated that the acquisition would have been the first step of a mega-merger by Telecom and Optus. Telecom and Optus would join forces to attack Telstra's position in the Australian market. This rumour has never been confirmed by either companies and subsequent events in the market have never indicated that this merger was ever going to take place. A possible explanation for this rumour may have been the fact that Optus had attempted to purchase AAPT in 1998 prior to Telecom but it was rejected by the Australian Competition and Commerce Commission (ACCC). ${ }^{12}$ Australian regulators believed that the merger would restrict market competition even more and narrow down the number of sizeable telecom companies to only two in the Australian telecommunications market.

A classic element of merger motivations is often the bad performance of a company's management. AAPT's has shown similar characteristics as well, the

\footnotetext{
${ }^{12}$ Australian Competition and Consumer Commission (http://www.accc.gov.au/content/index.phtml/itemId/475702)
} 
market (and Telecom's management too) believed that there was an opportunity for value creation by replacing the existing management and utilising the expertise of Telecom executives. What was not taken into account was that Telecom played a different role in its domestic market being the incumbent company trying to save its own interests and maintain its high revenue from the NZ market. AAPT was in a drastically different position being the attacker in the Australian market. This requires attitude, management style and strategy of different kinds to meet the challenges that this situation implies.

What both companies had to realise soon was that it is very difficult to compete outside their respective domestic markets. In the other country, both telcos are just one of the other competitors and even though their investment capacity may be significantly larger than any other players, they still have been hampered by strict regulations and consequently the high risk of building up their own network.

\section{Relevant events prior to Telecom NZ's takeover}

Prior to Telecom's plans to acquire AAPT, Optus had attempted to take over the company. This takeover attempt failed due to the rejection of the Australian Competition and Commerce Commission (ACCC).

Originally, Optus offered AU\$5 per share which was strongly rejected by AAPT's board and management. The chairman of the board, Mr Lee Casey, said at that time: "This opportunistic AU $\$ 5.00$ bid substantially undervalues the shares of the Company. It ignores the Company's growth potential and does not include any premium for control. We believe that AAPT represents a unique opportunity in the Australian market for CWO (Optus) and also for a number of international 
telecommunication companies with whom we are in discussion. The proposed CWO offer does not reflect AAPT's strategic value". ${ }^{13}$

Shortly after the release of Optus' offer, AAPT management released a report from investment bankers, Grant Samuel \& Associates which valued AAPT Limited in the range of AU\$6.04 to AU\$7.01 per share, which is $20.8 \%$ to $40.2 \%$ above Optus' conditional offer of AU\$5 per share.

Grant Samuel stated that "the valuation range of AU\$6.04 to AU\$7.01 per share reflects an expectation of substantial growth in AAPT revenues and earnings over the next few years flowing from investment by AAPT in infrastructure and changes in the regulatory environment. In the context of explosive growth in internet usage and data traffic, AAPT's infrastructure and established customer base provide a platform for dramatic growth," the report added. ${ }^{14}$

Grant Samuel also stated that it's valuation range may be conservative, adding: "In a competitive bidding situation, it is conceivable that industry participants seeking to establish a position or consolidate an existing position in the Australian telecommunications industry could offer higher prices to acquire the strategic number three competitor."

The above statements underline the fact that at the time analysts gave credit to the high growth forecast and as mentioned above most of it was based on the expectation of further easing up the regulatory regime.

\footnotetext{
${ }^{13}$ AAPT Ltd's Australia Stock Exchange announcement: "Directors Reject CWO Takeover Bid", Document date: 19 Apr 1999 (http://www.asx.com.au/asx/statistics/showSignalgDetail.do?issuerId=3829\&announcementId=576030 ${ }^{14}$ AAPT Ltd's Australia Stock Exchange announcement: "Grant Samuel values AAPT at \$6.04 to \$7.01 per share", Document date: 20 May 1999

(http://www.asx.com.au/asx/statistics/showSignalgDetail.do?issuerId=3829\&announcementId=576057
} 
Another possible reason for the original bid looking reasonably low in comparison is that we were in the middle of the dot.com boom when technological companies showed an unprecedented growth in stock prices and analysts worldwide would tend to put a significant emphasis on growth factor in their valuation models.

\section{Chronology of the takeover}

18 May 1999 TCNZ Australia Investments Pty Limited (wholly owned subsidiary of Telecom NZ) became a substantial shareholder in AAPT Limited with a relevant interest in the issued share capital of 29,588,430 ordinary shares $(9.9 \%)$. Telecom paid AU $\$ 5.70$ per share. Telecom indicated that "given Optus' bid for AAPT, Telecom felt it prudent to take a minority position in order to preserve its strategic options." 15

31 May 1999 Optus' withdrew its offer to buy AAPT's stake following ACCC's refusal of clearance for AAPT bid.

4 Jun 1999

TCNZ Australia Investments Pty Limited and associates increased its relevant interest in AAPT Limited from $29,588,430$ ordinary shares $(9.9 \%)$ to $59,149,859$ ordinary shares $(19.79 \%)$.

15 Sep 1999 Telecom New Zealand announced that its wholly owned subsidiary TCNZ Australia Investments Pty Limited would make an AU\$5.10 per share takeover offer for AAPT Ltd. The offer price of AU $\$ 5.10$ per share valued AAPT at approximatelyAU $\$ 1.5$ billion. The offer was for all of the AAPT shares that TCNZ Australia did not already own.

The share price of AAPT was AU $\$ 4.85$ on 30 August, prior to the run up of the last two weeks that appears to have been prompted by speculation about Telecom's intentions. The offer therefore represents a $5 \%$ premium.

15 The Dominion, 19 May 1999, Edition 2, Page 20. "Telecom tipped to expand into Australia" 
The Board of Directors of AAPT Limited considered the proposed take-over bid by TCNZ Australia Investments Pty Ltd and believed that the bid of AU\$5.10 was inadequate and undervalued the company. Accordingly, the Board recommended that shareholders reject the proposed offer.

In making this recommendation the Directors highlighted the following:

- Grant Samuel \& Associates Pty Ltd, assessed the value of the shares to be significantly above TCNZ's offer and accordingly has formed a view that the TNZ offer is not reasonable. Grant Samuel considered the fair value of shares to be between AU\$6.17 and AU\$7.14 a share.

- TCNZ was prepared to pay AU\$5.70 for 9.9\% of AAPT in May 1999 and after subsequent discussions with AAPT, TNZ made a non-binding proposal that in addition to purchasing Optus' stake at AU\$5.20 a share, TCNZ would subscribe to a AU $\$ 300$ million placement of AAPT's shares at AU\$6.00 a share.

- The TCNZ bid did not include a realistic premium for control of AAPT. The closing price of AAPT shares on ASX on the day prior to TCNZ's announcement, 14 September 1999, was AU\$5.15.

- The TCNZ offer reflected inadequate value for the significant growth potential attributable to investments and acquisitions that the company continues to undertake, in particular the expansion of AAPT's network.

21 Oct 1999

TCNZ Australia Investments Pty Ltd increased its relevant interest in AAPT Ltd from 59,154,859 ordinary shares $(19.79 \%)$ to $65,298,490$ ordinary shares $(21.80 \%)$.

25 Oct 1999

TCNZ Australia Investments Pty Limited increased its relevant interest in AAPT Ltd from 66,298,490 ordinary shares $(21.8 \%)$ to $71,878,903$ ordinary shares $(24.03 \%)$

1 Nov 1999 TCNZ Australia Investments Pty Ltd increased its relevant interest in AAPT Ltd from 71,878,903 ordinary shares $(24.03 \%)$ to $82,856,027$ ordinary shares $(27.71 \%)$. 
4 Nov 1999

Optus announced that, in the absence of a higher offer, it accepted Telecom New Zealand's takeover offer of AU\$5.10 for all its shares in AAPT Limited. The company's 10.6\% stake was purchased earlier in 1999 for AU $\$ 4.85$ per share in the course of the company's proposed takeover of AAPT.

Norman Gillespie, Deputy Chief Executive of Optus, said the company accepted the AU $\$ 5.10$ per share being offered by Telecom New Zealand. "Our earlier interest in AAPT was due to its perceived strength in the SME and Government markets. When our bid for AAPT was blocked by the ACCC we concentrated our efforts on winning business in these markets, which has met with considerable recent success. We no longer require a strategic stake in AAPT, and selling to Telecom New Zealand gives us the opportunity to exit the shareholding at a profit."16

4 Nov 1999

TCNZ Australia Investments Pty Ltd increased its relevant interest in AAPT Ltd from 82,866,027 ordinary shares $(27.71 \%)$ to $97,964,251$ ordinary shares $(32.76 \%)$.

5 Nov 1999

John Fairfax Holdings Limited said that AAPIS, in which it holds a 44\% stake, had accepted, through its subsidiary, AAP Communications Holdings Pty Ltd (AAPCH) accepts Telecom New Zealand's offer of AU\$5.10 per share pursuant to TCNZ's bid for AAPT Ltd.

Mr Fred Hilmer, Chief Executive Officer of Fairfax, said, "This decision is consistent with our objective to realise shareholder value by relinquishing our position in non-core assets." ${ }^{17}$

6 Nov 1999

TCNZ Australia Investments Pty Ltd, closed its offer for the shares in AAPT Ltd after successfully obtaining close to $80 \%$ of the shares.

\footnotetext{
${ }^{16}$ AAPT Ltd's Australia Stock Exchange announcement: “CWO`s ann: Optus to accept Telecom NZ offer for AAPT", Document date: 04 Nov 1999

(http://www.asX.com.au/asx/statistics/showSignalgDetail.do?issuerId=3829\&announcementId=576180

${ }^{17}$ AAPT Ltd's Australia Stock Exchange announcement: "FXJ`s ann: Stmnt.by John Fairfax Holdings Limited on AAPT", Document date: 05 Nov 1999

(http://www.asx.com.au/asx/statistics/showSignalgDetail.do?issuerId=3829\&announcementId=576187)
} 
AAPT's Chairman, Mr Lee Casey, said: "We are obviously a little surprised that a number of our institutional shareholders sold at the low price offered. Telecom has bought very well and we now look forward to working with them to continue to deliver the exceptional returns that AAPT has delivered to date." 18

10 Nov 1999 AAPT announced that Telecom's CEO, Theresa Gattung and Chief Financial Officer, Mr Jeff White, joined the AAPT Board of Directors.

\section{Empirical study on announcement effects}

I applied the standard event study method and examined the abnormal returns to shareholders of both TCNZ and AAPT for the period around several important announcements. I highlighted four key announcements in the process of the takeover and calculated abnormal returns for both companies' share performance. The abnormal return (AR) is by definition a return on the share on a particular day above a benchmark of what investors require on that day. The benchmark I applied was ASX All Ordinaries index for Australia and NZALL for New Zealand. All the announcements and their corresponding dates are obtained from the Australian Stock Exchange. The parameters of the market model, applying the regression model, are calculated using 130 observations, starting 150 days before the 20days before and after the considered events. Our findings are reported in Table 1.

\footnotetext{
${ }^{18}$ AAPT Ltd's Australia Stock Exchange announcement: "Media Release: Telecom Offer for AAPT Closes", Document date: 08 Nov 1999

(http://www.asX.com.au/asx/statistics/showSignalgDetail.do?issuerId=3829\&announcementId=576193
} 


\section{Event study results*}

\begin{tabular}{|c|c|c|c|c|c|c|}
\hline Events & Date & Anvouncement & $\begin{array}{l}\text { AAPT } \\
\text { AR }\end{array}$ & $\begin{array}{l}\text { AAPT } \\
\text { t Test } \\
\end{array}$ & $\begin{array}{c}\text { TCNZ } \\
\text { AR } \\
\end{array}$ & $\begin{array}{l}\text { TCNZ } \\
\text { t Test } \\
\end{array}$ \\
\hline 1 & 18 May 1999 & Telecom purchased of $9.9 \%$ of AAPT shares & $-0.52 \%$ & -0.23 & $-1.57 \%$ & -1.45 \\
\hline 2 & 4 Jun 1999 & Telecom increased its stake to $19.79 \%$ & $3.58 \%$ & 1.58 & $-0.38 \%$ & -0.35 \\
\hline 3 & 15 Sep 1999 & $\begin{array}{l}\text { Telecom made a public offer to purchase the } \\
\text { remaining shares of AAPT }\end{array}$ & $-0.40 \%$ & -0.18 & $-1.14 \%$ & -1.06 \\
\hline 4 & 5 Nov 1999 & Telecom NZ becomes majority shareholder & $-0.68 \%$ & -0.30 & $-1.03 \%$ & -0.95 \\
\hline
\end{tabular}

\footnotetext{
* The estimation period is from -150 to -20 days prior to the announcements. $t$ stat is the heteroskedasticity-adjusted $t$ statistics for the Average Abnormal return. It tests the null hypothesis that the Average Abnormal Return $=0$.
}

Most international studies indicate significant positive returns for target shareholders and small negative or zero returns for bidders (Bruner 2002). Studies conducted on New Zealand (Firth 1997) and Australian (Walter 1984) markets further confirm these findings.

The market reactions to Telecom's acquisition show similar results in relation to bidder abnormal returns. The daily ARs for the bidder company for all announcements are negative ranging from $\mathrm{AR}-0.38 \%$ to $-1.57 \%$, though none of them statistically significant. These results support the international findings, namely the markets do not value cross-border acquisitions from the bidder company's perspective.

The results in relation to the target company are also supporting earlier studies though not that strongly. Specifically, AAPT's abnormal returns are distributed from $-0.40 \%$ to $3.58 \%$. On average, it indicates modest positive abnormal returns which are in line with other studies but the magnitude is reasonably smaller than worldwide benchmarks. 


\section{Post acquisition performance}

Shortly after the takeover Telecom established a working group comprising Telecom and AAPT management which identified the following areas of synergies:

- joint management and purchasing of international traffic and bandwidth;

- operating cost savings and reducing capital expenditure through the coordination of domestic networks;

- joint marketing to major corporate businesses operating trans-Tasman by promoting a seamless service;

- alignment of respective mobile capabilities, including trans-Tasman roaming, handsets, operations, maintenance and marketing;

- skills transfer between management teams, particularly in local, trans-Tasman virtual private networks, xDSL, copper and mobiles; and

- co-operation of internet and e-commerce initiatives and the creation of a content alliance.

As a result, during 1999 and 2000 Telecom consolidated many of AAPT's activities and ultimately ended up fully integrating the two companies. As a consequence AAPT, being active in reorganising itself, had lagged behind Optus who had taken the lead in competitive activities in the telecommunications market. At the same time AAPT has replaced many of its top executives including the CEO. ${ }^{19}$

\footnotetext{
${ }^{19}$ AAPT Company Analyses - Paul Budde Communications Pty Ltd (2006)
} 
Telecom's plan was to establish a genuine trans-Tasman business by bringing together the Internet and Mobile businesses of Telecom and AAPT under an integrated management team. Telecom's new chief executive Theresa Gattung said that "Expansion in Australia is a core strategy for the group, and we're putting in place a strong platform for expansion through AAPT and TCNZ Australia, and the focused Internet and Mobile businesses." 20

During 2000, AAPT and Telecom NZ achieved success in working together to secure telecommunications business on both sides of the Tasman for New Zealand corporates. AAPT won major contracts represented total annual revenues of AU\$6 million. The contracts include New Zealand-based forest, building and paper products company Carter Holt Harvey, food group Heinz Wattie's Australasia and Owens Group, a major transport and logistics business. Telecom was now able to deliver a full range of telecommunications services and the facility to consolidate their telecommunications arrangements. Previously these companies had arrangements with Telstra and other third party providers for their Australian operation.

Despite some encouraging initial customer acquisition, the restructuring and change in management seemed to have had its backside. It became apparent that

\footnotetext{
${ }^{20}$ AAPT company announcement; "TELECOM-AAPT Integration Progressed" (http://www.aapt.com.au/news/content.asp?n=95
} 
even the combined New Zealand \& Australia market would not be sufficient for future growth. In the meantime other telecommunication providers have taken the opportunity to drive competition in Australia. Also, some of Telecom NZ's problems seemed to have been exported to AAPT's market as well, namely a flat national market with rapidly shrinking revenues and profit margins, issues with the competition in the mobile area and non-compatible network technologies etc. It has been proven that combining an incumbent player in one market with an attacker in the other is extremely challenging. By mid 2001, Telecom had to reduce the value of AAPT in its books by approximately NZ\$1 billion.

Another important factor has been that Telstra has always maintained wholesale prices at such level that it was not motivating other competing Telcos to invest into building up a complete network that would have been able to operate independently. At the same time, wholesale prices were not placed at a sufficiently low level in order to maintain an acceptable rate of return for smaller players in the market.

Telecom NZ had realised the importance of a strategic change and laid down a new direction for AAPT starting from late 2002 that involved a disintegration of the two companies and acknowledging the fact that they operate in two different markets in completely different market positions. The new strategy aimed to focus 
on various niche markets where by concentrating forces AAPT could successfully challenge the more significant players.

The shift in strategy also involved that AAPT discontinued operating as a universal service provider and abandoned its broader residential market and began cross-selling between its various divisions such as fixed line, mobile, internet, etc. The company set up specific sales teams focusing on selling packaged products to specific markets. The new initiatives in repositioning the AAPT brand was accompanied by an extensive cost-cutting project as well. While some of the resale margins continued to be remarkably low, bundling of the various products seemed to be a successful strategy. This strategy was supported by a AU $\$ 20$ million advertising campaign.

Despite the efforts of AAPT trying to maintain its profitability and compete in the market, it has become evident that the current industry structure makes it enormously difficult for second tier companies to distinguish themselves and build up a genuinely different product range. Companies such as AAPT had to struggle with the fact that they can only sell what Telstra offers them at a price suitable for Telstra. Whilst several big players have ceased to exist, it was quite an achievement for AAPT just to be around and still be able to compete with other major Telcos. 
In 2005 Australian government decided to divest the remaining stake in Telstra (51\%). This move has had a number of implications on other players in the telecommunications market including AAPT. Before selling out Telstra's shares, the government wanted to strengthen the company's position in the market. This has resulted in an extreme situation when Telstra went as far as bringing down its retail price under wholesale price. ${ }^{21}$ The immediate impact on AAPT was that in October 2005, Telecom decided that again it needs to restructure the operation by looking at options that include a potential sale of the business.

\footnotetext{
${ }^{21}$ AAPT Company Analyses - Paul Budde Communications Pty Ltd, 2006
} 


\section{VALUATION OF AAPT}

Due to the reasons mentioned earlier, AAPT's acquisition can be considered as a complicated one. The returns generated by the company have been lower than planned and various restructurings by Telecom's management attempted to remedy the position and improve AAPT's profitability. In a situation like this it is worthwhile to look at AAPT's financials in more detail.

Valuation plays a pivotal role in any acquisition analyses. It is imperative for bidders to determine the value of the company in order to establish the bidding price they are prepared to pay for the stake of the targeted company. It is equally important for target management and stockholders to be aware of the value of their company for being able to make decisions on whether they should accept or reject the offer.

International acquisitions have shown a significant increase in the last 15-20 years and they proved to be one of the primary tools in corporate strategy. Many CEOs consider acquisition as the simplest way to expand their operation and there are an increasing number of international expansions in recent years. ${ }^{22}$

\footnotetext{
${ }^{22}$ Hawawini, G., Valuation of Cross-Border Mergers and Acquisitions, 1992
} 
International acquisitions have two major drivers. Firstly, there is a shift in managers' approach to investing internationally. The world is becoming smaller and a venture to the other side of the world does not seem so remote any more. Secondly, today's advanced technology provides efficient and cost effective communication channels to better control overseas interests. Third and most evident motivation is the cost savings companies can incur by investing overseas.

Valuation becomes particularly important in cross border acquisitions. In this chapter, I will provide a valuation analysis on AAPT applying the discounted cash flow method (DCF).

One of the most important and commonly used valuation methods is DCF. There are a large number of DCF models in existence that are being used by market participants; however most of them are a variant of the main DCF models, namely:

- Equity valuation

- Firm valuation

- Adjusted Present Value (APV) valuation

The Equity valuation model is for valuing the equity stake of a company. Firm valuation applies a model which focuses on valuing the whole company including the value that belongs to other claimholders. APV is used for valuing the 
companies in parts, assuming that it is financed only by equity capital and then it is adjusted by the effects on value of debt and other non-equity claims.

\section{Valuation model}

In order to assess AAPT's value, I applied the DCF firm valuation method and developed a comprehensive financial model. The model demonstrates the key value drivers of the business, namely revenues for the main revenue streams, the corresponding costs and capital expenditure. The model applies a growth rate for all these drivers for the period of $2001-2007$ after which a perpetual growth rate is used. The business drivers and their growth rates are based on historical financial data (set of accounts for 1998 - 2000) and a number of assumptions for the key business drivers and the impacts of various initiatives in the business. The model does not apply any actuals after 2000 as the intention is to model the situation at the time of the acquisition.

Based on the value driver estimates, the future cash flows generated by the company are calculated and discounted by applying an appropriate discount rate. These figures will be explained in detail later in this chapter. 


\section{DCF valuation summary}

The value of the business has been assessed and the discounted cash flow analysis resulted in a value of AU $\$ 4.33$ per share. The full value per share summary is as follows:

\begin{tabular}{|lcr|}
\hline Total Value of AAPT's Assets (AU\$ '000) & $\$$ & 1,561 \\
\hline Less value of debt & $\$$ & 240 \\
Value of equity & $\$$ & 1,321 \\
Shares outstanding & & 305 \\
\hline Value of equity per share (AU\$) & $\$$ & 4.33 \\
\hline
\end{tabular}

Telecom's original offer for AAPT's shares was AU\$7.25 per share. It is substantially higher than it was found in this analysis. This can by explained by two distinct factors: firstly the model does not take into account any synergies between the two businesses. Secondly, though this model applies quite substantial revenue growth, Telecom's offer contains even more ambitious growth figures.

The value of AAPT is very sensitive to a number of key elements, namely pricing, the ability to continue building up its market share and wholesale terms and interconnect charges. These factors are the most difficult to predict for the future.

It is imperative to recognize the risks around the valuation which are associated with the Australian telecommunication business and the telco business in general: 
- Aggressive competition responses and new initiatives from the incumbents. Due to the market size and investment capacity of the incumbents, they are able to finance negative cash flow projects to gain market share and start realising returns later when the smaller competitors have left that segment of the business.

- New entrants in the market. It is always a risk that a major international telco enters the Australian market and with its international expertise and capital strength it can grow into a major competitor in short period of time.

- Regulatory change. As described in previous chapters, this is a major issue for telcos in Australia. A regulatory change can cause a realignment of the whole market with winners on one side and losers on the other, depending on the nature of the regulatory change. The importance of this incremental risk cannot be underestimated.

- Technological change. This is a constant risk factor in the telco industry the product range is continuously changing and new more advanced products replace the old ones often in a short period of time.

The above factors make telco valuations particularly challenging. Despite these risk factors, AAPT has important strengths that can contribute to the company's success. In the previous years, AAPT has been successful in: 
- managing growth,

- developing new businesses

- increasing customer base and market share

- implement strategic acquisitions

- capitalise on future growth opportunities (new applications and products)

\section{Revenue}

The model calculates the revenue until 2007 based on the growth rates from 19982000 and projected for the future periods. Total revenue is forecast to grow from AU $\$ 942 m$ to $A U \$ 3,058 m$ in 2007. From 2007 a perpetual growth rate of $5 \%$ is applied - it is based on a projected GDP growth rate. The weighted average revenue growth across the different segments for the 2001- 2007 period is $19 \%$. 


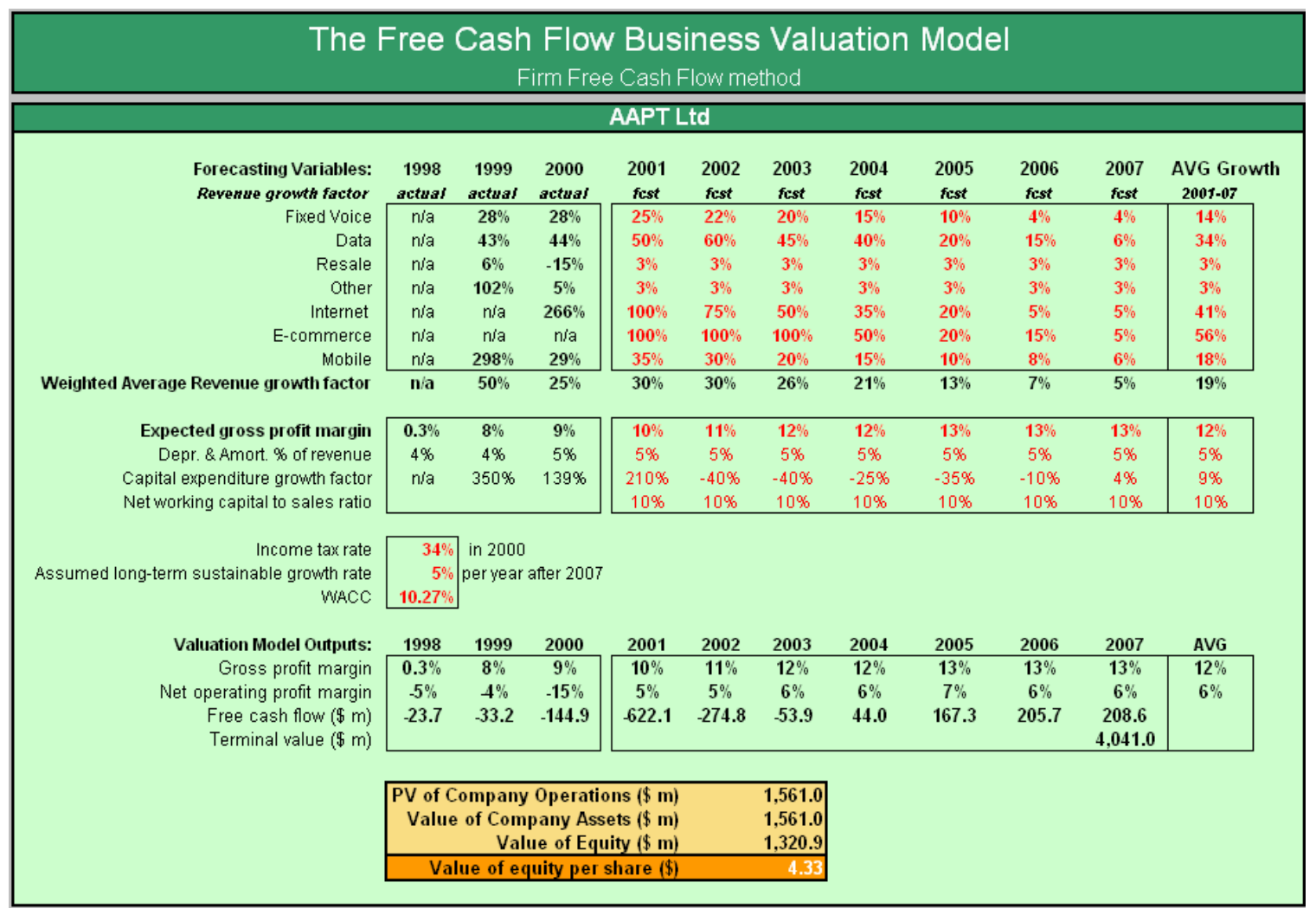

This revenue growth reflects the long term prospects in the telecommunication sector and implies the substantial growth in traffic partly offset by declining pricing. The majority of the growth stems from the data traffic and internet ecommerce, however their volume level is lower compared to the traditional income stream as fixed voice services.

Despite international and local market trends, fixed voice services will show increase in the future years, but AAPT was projected to gain market share in the shrinking fixed voice market especially in the business and government customer base. 


\section{Operating Costs and Capital expenditure}

Operating expenses have been built up based on the expected operating margins across the $2001-07$ period. In the model, a modest increase is projected for the upcoming years, starting from $10 \%$ in 2001 and going up to $13 \%$ in 2007 . The gross margin will increase driven by growing volumes and the corresponding effect of the economies of scale and cost savings initiatives across the board.

Capital expenditure will increase quite considerably in 2001 and start flattening off from the 2002 onwards. The main capital expenditure will be spent on the new CDMA network (AU\$530m in 4 years) and AU\$120m on leasing from Optus network capacity. Further investments will be made on enhancements of the Southern Cross cable and developments of the local access network.

\section{Sensitivity analysis}

\begin{tabular}{|c|c|c|}
\hline \multicolumn{3}{|l|}{ Sensitivity analysis $(000)$} \\
\hline Net present value based on the assumption in the financial model & $\$$ & 1,321 \\
\hline \multicolumn{3}{|l|}{ Variations to the assumptions: } \\
\hline \multicolumn{3}{|l|}{ Discount rate } \\
\hline $11.27 \%$ & $\$$ & 889 \\
\hline $9.27 \%$ & $\$$ & 1,956 \\
\hline \multicolumn{3}{|l|}{ Perpetual revenue growth rate } \\
\hline $6 \%$ & $\$$ & 1,894 \\
\hline $4 \%$ & $\$$ & 1,028 \\
\hline \multicolumn{3}{|l|}{ Gross profit for the terminal period } \\
\hline $14 \%$ & $\$$ & 1,629 \\
\hline $12 \%$ & $\$$ & 1,002 \\
\hline \multicolumn{3}{|l|}{ Capital Expenditure for the terminal period } \\
\hline $5 \%$ & $\$$ & 1,310 \\
\hline $3 \%$ & $\$$ & 1,332 \\
\hline
\end{tabular}




\section{Net present value (NPV)}

Based on the above variables, the free cash flow to the firm was calculated. The NPV analysis applies a discount rate of $10.29 \%$. The discount rate for the purpose of this analysis was derived from the application of the weighted average cost of capital (WACC). The WACC is based on the weighted average cost of equity and cost of debt.

\section{Cost of Equity}

The cost of equity is the return that equity investors require on their investment in the firm. The cost of equity is derived from the capital asset pricing model (CAPM). CAPM is the most commonly accepted model. It can be explained as the shareholders' expectation of a return that is at least equal to the risk free interest rate, increased by a premium for the risk they take. The risk premium is the difference between the risk free rate and the current market rate multiplied by a variable that reflects the volatility of the equity price, i.e. its risk.

$$
r_{e}=r_{f}+\beta \times\left(r_{m}-r_{f}\right)
$$

$$
\text { where } \quad \begin{array}{ll}
\mathrm{r}_{\mathrm{f}}=\text { risk free rate } \\
\\
\mathrm{r}_{\mathrm{m}}=\text { expected market return } \\
& \beta=\text { risk factor }
\end{array}
$$


Risk free rate of $6.3 \%$ applied in this model. It is based on yield to maturity on the 10 year Australian Commonwealth Government Bonds. ${ }^{23}$

Risk premium of $6.0 \%$ has been used. ${ }^{24}$ This figure represents the additional risk that is associated with the equity market in Australia in September 2000 and based on a geometric average of returns over a period of several years.

Beta factor of 0.84 has been used. This number is based on the relative returns of AAPT against the ASX All Ordinaries index since AAPT got listed in 1997. A weighted averaged of the industry beta is 0.91 . That figure is an average of betas of the largest Australian and New Zealand telcos such as Telecom NZ, Telstra, Optus, One.Tel etc. This indicates that AAPT's beta is reasonably close to the industry average.

\section{Cost of Debt}

The cost of debt measures the cost of borrowing funds to finance a project, in other words, it is the rate of return the firm's creditors demand on new borrowing. The cost of debt can be set out by the following variables:

- Risk free rate The risk free rate is usually obtained by using the return rates of long term government bonds. If the risk free rate increases the cost of debt will immediately follow

- The default risk (and default spread) of the company. As the default risk increases the cost of debt will increase accordingly.

\footnotetext{
${ }^{23}$ Offer by TCNZ Australia Investments Pty Ltd, 15 Sep, 2000 ACN 087384825

${ }^{24}$ Offer by TCNZ Australia Investments Pty Ltd, 15 Sep, 2000 ACN 087384825
} 
- Tax advantage associated with debt. Since interest is tax deductible, the after tax cost of debt is a function of the tax rate.

The cost of debt can usually be observed by looking at the interest rates the companies have to pay on new borrowings in the financial markets. For example, if the firm already has outstanding bonds, the yield-to-maturity on those bonds is the rate on the firms debt required by the market.

In a situation where a firm's issued bonds are not traded on a regular basis, another approach is required in order to determine the cost of debt. When this occurs, the cost of debt can be estimated from the company's rating and the associated default spreads. The rating is an indicator of a company's default risk. The higher the rating the less likely it is that the company will fall over. There is a default spread associated with the ratings which shows the premium companies have to pay on the top of the risk free rate in order to obtain debt capital from the markets.

If there is no rating available for the company, there are still alternatives to obtain the cost of debt. One example is by looking at the companies' recent borrowing history. Even though these companies do not have issued bond traded on the market or they are not rated, they still may borrow money from financial institutions. If they do so, the most recent borrowing rates can be observed and that can be a good indication as to the default spread of the company and can be used as a close estimate to the cost of debt.

Another alternative is to construct a synthetic rating. The means that the analyst can do the job of a rating agency i.e. calculate the default risk from financial ratios available and apply this rate for the cost of debt. 
In the analysis an after tax cost of debt figure of $7.5 \%$ was applied. This rate was calculated on the basis of AAPT's expected cost of borrowing from 2000 over the duration of the cash flow model.

Debt/Equity mix has been estimated as $14 / 86 \%$. This is a representation of the actual mix in September 2000 and it is expected that this ratio will remain unchanged for the following years.

\section{Weighted Average Cost of Capital}

In the earlier chapters the main sources of capital have been presented. When a firm uses different sources of funding (equity and debt), the expected return on the firm's capital is calculated as a weighted average of the cost of capital of the various sources. In other words, it is the overall return the firm must earn on its existing assets in order to maintain shareholders' value. It is also a good measure of comparing companies' risk exposure.

The calculation of WACC is as follows:

$$
\mathrm{WACC}=\mathrm{k}_{\mathrm{e}} \times \mathrm{E} / \mathrm{V}+\mathrm{k}_{\mathrm{d}}(1-\mathrm{t}) \times \mathrm{D} / \mathrm{V}
$$

$$
\begin{aligned}
& \text { Where } \quad \begin{array}{l}
\mathrm{k}_{\mathrm{e}}=\text { cost of equity } \\
\mathrm{k}_{\mathrm{d}}=\text { cost of debt } \\
\mathrm{E} / \mathrm{V}=\text { the proportion of the equity value relative to the } \\
\quad \text { market value of the firm }
\end{array}
\end{aligned}
$$




$$
\begin{aligned}
& \mathrm{D} / \mathrm{V}=\text { the proportion of the debt value relative to the } \\
& \text { market value of the firm } \\
& \mathrm{t}=\text { tax rate }
\end{aligned}
$$

In the model a WACC of $10.27 \%$ has been estimated. This is an after tax discount rate to be applied to nominal ungeared after tax cash flows.

Some reservations need to be expressed in relation to the model:

- CAPM theory is based on expectations but applies historical data as proxy

- Measurement of historical data especially risk premium and beta factors are subject to considerable statistical error and can vary widely depending on the selected time periods, benchmark returns and markets

- Some of the data applied are based on judgement calls, e.g. the application of the right debt/equity mix 


\section{CONCLUSIONS}

This paper provides an overview of a cross-border takeover in the telecommunication sector, the Telecom New Zealand acquiring of AAPT in Australia. I analyse the telecommunication markets internationally as well as in New Zealand and Australia including their regulatory environment. The paper highlights the main strategic decisions that led to the takeover and analyses the post merger performance. It was found that the regulatory environment is very restrictive for market players competing with the incumbent telecommunication company, Telstra, and it had a significant impact on the company's performance subsequent to the takeover. I also conduct an event study and find that market reactions are rather weak which is in line with empirical findings of earlier crossborder studies. I conclude the study with a valuation analysis. 
APPENDIX - Milestones in AAPT's history

1991 AAPT was established

Granted a Service Provider's Class License in accordance with the Telecommunications Act

1992 Negotiated an interconnect agreement with Telstra

1993 Installed switches into selected regional centres

1994 Established submarine cable links to USA

1995 Offered mobile services through Vodafone's network

Acquired 50\% of ISP Connect Internet Solutions

1996 Acquired 40\% of Cellular One Communications. The company distributed its mobile services through over 120 dealer stores. It was also Vodafone Network's largest independent service provider, accounted for almost 20 per cent of Vodafone Network's customer base.

1997 Awarded a carrier licence

Listed on ASX, raising AU\$76 million for the public issue of new shares and becoming first Australian carrier to be listed on the ASX

1998 Acquired the remaining 60\% of Cellular One Communications

Purchased the outstanding $80.5 \%$ of corpTEL, a long distance voice provider

AAPT and Optus announced an agreement between the two companies for the provision of mobile communication services across the Optus network for AAPT's customer base.

Acquisition of $100 \%$ of Ozphone Pty Ltd that gave AAPT control of its CDMA mobile network spectrum which combined with existing AAPT spectrum enabled coverage of over $50 \%$ of the Australian population.

Acquisition of $100 \%$ of AT\&T Easylink Services Australia Pty Limited, an e-commerce solutions provider. The acquired entity was re-branded and in 
conjunction with connect.com lead the provision of e-commerce solutions to the high growth business sector.

1999 Telecom NZ acquired $80 \%$ of the company's shares

Acquired the remaining shares in ISP Connect Internet Solutions

Fibre optic local-loop networks completed in the CBDs of the five major cities in Australia

2000 Telecom NZ acquired the remaining $20 \%$ of the company

Voice and Data operations were split into two divisions

De-listed from ASX

Acquire national high bandwidth network capacity from Optus

2001 Formed joint venture with America Online and Seven Network, AOL7

2002 AAPT's international telecommunications business transferred to Telecom NZ's International division

AAPT Cellular One signed a three-year CDMA wholesale agreement with Telstra

2003 AAPT Mobile launched its AAPT Mobile Wholesale Service

2004 Divested its stake in AOL7 


\section{REFERENCES}

Australian Government's Australian Communication and Media Authority's website (www.ama.gov.au $)$

Australian Competition and Consumer Commission's website (http://www.accc.gov.au/content/index.phtml/itemId/475702)

Australia Telecoms Industry - Overview and Statistics 2005/2006, Paul Budde Communications Pty Ltd.

AAPT Company overview - Paul Budde Communications Pty Ltd, 2006.

AAPT Company Analyses - Paul Budde Communications Pty Ltd, 2006.

APT Ltd annual report 1999.

AAPT Ltd website (www.aapt.com.au $)$.

Boylaud, Olivier and Giuseppe Nicoletti, 2000, Regulation, Market Structure and Performance in Telecommunications, Economics Department Working Papers No.237, OECD, Paris

Bruner, R., 2002, Does M\&A pay? A survey of evidence for the decisionmaker, Journal of Applied Finance, Spring/Summer 2002, pp.7-27.

Company announcements on Australian Stock Exchange website (www.asx.com.au). 
Corhay A., Tourani-Rad, A., 2000, International acquisitions and shareholder Wealth: evidence from the Netherlands, International Review of Financial Analysis 9, 163-174.

Country Profile, Australia, hottelecom, Nov. 2004.

Country Profile, New Zealand, hottelecom, Nov. 2005.

Datta, A. and Agarwal, S., 2004, Telecommunications and economic growth: a panel data approach. Applied Economics, 36:1649-1654

Doukas, J., Travlos, N.G., 1988, The effect of corporate Multinationalism on shareholders' wealth: evidence from international acquisitions, Journal of Finance 43, 1161-1175.

Fatemi, A., Furtado, E.P., 1988, An empirical investigation of the wealth effects of foreign acquisitions, in: Kouri, S., Ghosh, A. (Eds.), Recent Developments in International banking and Finance, Vol. 2. Lexington, MA, pp. 363-379.

Firth, M., 1997, Takeovers in New Zealand: motives, stockholder returns, and executive share ownership, Pacific-Basin Finance Journal 5, 419 - 440.

Giray, Filiz, 2006 The Privatisation and Market Liberalisation of Telecommunications in Turkey, Telecommunications Journal of Australia, Vol 56 No 2 
Greenstein, S. M. and Spiller, P. T., 1995, Modern Telecommunications Infrastructure and Economic Activity: An Empirical Investigation. Industrial and Corporate Change. Vol. 4. No. 4: 647-665

Hawawini, G., Valuation of Cross-Border Mergers and Acquisitions, Finanzmarkt und Portfolio Management, 1992/1, 38-60.

Kang , J.K., 1993, The international market for corporate control, Journal of Financial Economics 33, 345-371.

Markides, C.C., Ittner, C.D., 1994, Shareholder benefits from corporate international diversification: evidence from US international acquisitions, Journal of International Business Studies 25, 343-366.

Offer by TCNZ Australia Investments Pty Ltd, 15 Sep 2000, ACN 087384825

Telecom NZ Ltd annual reports 1998 - 2005.

Telecom NZ's website (www.telecom.co.nz).

Telecoms overview, statistics and analyses in New Zealand 2006, Paul Budde Communications Pty Ltd.

Telstra Australia annual reports $2004-2005$.

Walter, T.S., 1984, Australian takeovers: Capital market efficiency and shareholder risk and return, Australian Journal of Management 9, 63 - 95 
Website of Australia's Department of Communications, Information Technology and the Arts

(http://www.dcita.gov.au/tel/connect_australia/operational_separation) 